\title{
Стратиграфия неоплейстоцена Кольско-Карельского региона в контексте Международной стратиграфической шкалы
}

\section{Корсакова О.П.}

Геологический институт КНЦ РАН, Anamumb, korsak@geoksc.apatity.ru

Аннотация. В статье рассматривается состояние региональной стратиграфической схемы, официально принятой для неоплейстоцена Кольско-Карельского региона. Приводится ее корреляция с Международной стратиграфической шкалой, рассматриваются вопросы терминологии.

Ключевые слова: литостратиграфия, климатостратиграфия, региональные стратиграфические подразделения.

\section{Neopleistocene stratigraphy in the Kola-Karelian region in the context of International Stratigraphy chart}

\author{
Korsakova O.P. \\ Geological Institute KSC RAS, Apatity, korsak@geoksc.apatity.ru
}

\begin{abstract}
The article discusses the state of the regional stratigraphic scheme officially adopted for the Neopleistocene of the Kola-Karelian region. Its correlation with the International Stratigraphy chart is given; stratigraphy terminology is considered.
\end{abstract}

Key words: lithostratigraphy, climatostratigraphy, regional stratigraphic units.

Since regional stratigraphic records are fragmentary and often lacking reliable dating techniques covering the full range of Neopleistocene, stratigraphical schemes sometimes are faced with problematic cross-regional and global correlations. The aim of this paper is to review the data from Kola-Karelian stratigraphy key sites in the context of the International Stratigraphic chart (IS chart), which differs from the General Quaternary Stratigraphic chart of Russia (GQS chart of Russia) (Table 1).

\section{Material and terminology}

GQS chart of Russia supposes original Quaternary System subdivisions, such as Pleistocene Superseries, include Eopleistocene and Neopleistocene Series. The Eopleistocene Series is compared to the Lower Pleistocene combining Gelasian and Calabrian Stages. Moreover, the Neopleistocene Series correlates to the Middle and Upper Pleistocene in the IS chart. The Neopleistocene Series is subdivided into the lower (I), middle (II) and upper (III) Links that correspond to the lower Middle Pleistocene, upper Middle Pleistocene, and Upper Pleistocene in the IS chart, respectively (Table 1). Each link comprises rock complexes that formed during several interglacial-glacial climatic rhythms (Zhamoida et al., 2006) and generally correspond to subseries in the IS chart (Table 1). Stratigraphic units subordinated to a link in the rank called steps. Each step refers to a sequence of rocks deposited during global climatic warming or cooling. In the GQS chart of Russia correlated with the Marine Isotope Stages (MIS) 19-12, MIS 11-6 and MIS 5-2, the lower, middle and upper links of the Neopleistocene Series include eight, six and four steps, respectively (Table 1). A stage can be considered as an international stratigraphic equivalent of a step.

A horizon is the most common stratigraphic unit in the GQS chart of Russia. It is a primary regional stratigraphic unit with geographic name after a regional type section, i.e. a stratotype. A horizon integrates laterally various even-aged formations and groups or their parts (in a section), accumulated in different facies/ environmental zones of a single sedimentary palaeobasin. Horizons are applied to make correlations within their areal and to compare regional stratigraphic charts with the GQS chart of Russia (Zhamoida et al., 2006; Zastrozhnov et al., 2014). Superhorizons are supplementary regional stratigraphic units that group several horizons into a bigger regional unit; a superhorizon comprises several groups or supergroups. Even though horizons and superhorizons are generally regional lithostratigraphic subdivisions, they can be identified based on the climatostratigraphy. In practice, they can be mapped on different-scale (1:1000000-1:50000) 
Quaternary maps. In the regional stratigraphic nomenclature, the beds are the smallest formal geographically named unit. It includes several undisturbed strata with similar lithology and/or biostratigraphy (Zhamoida et al., 2006). The beds are a subdivision of a horizon, while it is not necessary that a horizon is entirely or partly divided into beds. In the framework of the international lithostratigraphy hierarchy, the beds are closest to a member.

The names of regional stratigraphic subdivisions that are mentioned in this paper are provided as transliteration from Russian terms according to the recent Map of Quaternary formation of Russian Federation (Zastrozhnov et al., 2014).

Таблица 1. Главные соотношения основных стратиграфических подразделений.

Table 1. Principal correlation of the main stratigraphic units.

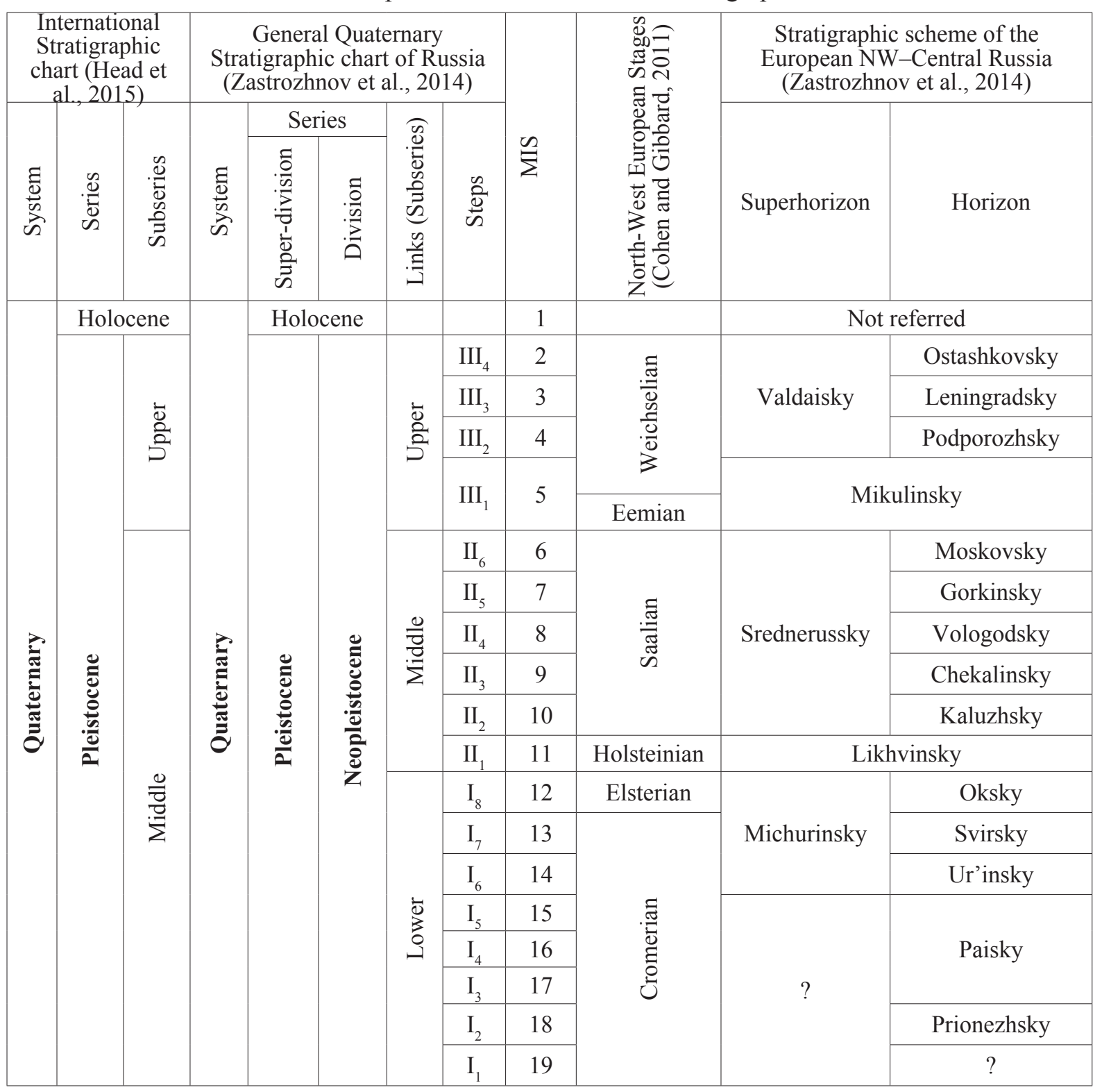

A review of data includes the key site/sections with Neopleistocene (Middle and Upper Pleistocene in the Europe) stratigraphic units that were identified according to lithological and multi-proxy (pollen, diatoms, foraminifera, and others) evidences in the Kola-Karelia region. Deposits of stratigraphic subdivisions from the Kola region are geochronometrically $\left({ }^{14} \mathrm{C},{ }^{230} \mathrm{Th} / \mathrm{U}\right.$, ESR or OSL) dated; single sediment successions are only ${ }^{14} \mathrm{C}$ dated in the Karelia.

Lower Neopleistocene (pre-Holsteinian Middle Pleistocene in N-W Europe) glacial and interglacial deposits have been found by drilling in southern Karelia. Their relative age has been approximately derived 
from their positions in the sediment succession. Lacustrine and fluvial clayey sediments of the interglacial Paisky horizon (c. MIS 15-17 in Table 1) and glacial loam of the Prionezhsky and Ur'insky horizons (c. MIS 18 and 14, correspondently) are probably presented in the boreholes at the Pay Village in central part of the Onega-Ladoga Isthmus (c. 61.2023 N, 34.4495 E). Glacial diamicton of the Oksky horizon (MIS 12) occurs in southern Karelia between the Svirsky (c. MIS 13) and Likhvinsky (MIS 11) interglacial horizons in the sediment succession known from borehole near Orzega Village, western Coast of the Onega Lake (c. $61.6459 \mathrm{~N}, 34.4858 \mathrm{E}$ ); glacial diamicton with $18 \mathrm{~m}$ thickness is identified here under Likhvinian interglacial deposits in the borehole situated near Matrosy Village (c. 61.7628 N; 33.7973 E) (Agranova and Gaigerova, 1973; Akromovskiy et al., 2000).

Middle Neopleistocene (upper Middle Pleistocene in N-W Europe) includes the interglacial Likhvinsky (MIS 11), Chekalinsky (MIS 9), and Gorkinsky (MIS 7) horizons and the glacial Kaluzhsky (MIS 10), Vologdsky(MIS 8), and Moskovsky (MIS 6) horizons, which correlate to the Middle Pleistocene Holsteinian and Saalian Series in N-W Europe (Table 1). Key sites Matrosy (c. 61.76280 N; 33.79726 E) and Orzega (c. $61.6459 \mathrm{~N} ; 34.4858$ E) on the Onega-Ladoga Isthmus in southern Karelia proved the sediment succession included interglacial marine and lacustrine clay and degraded paleosoil with pollen spectra of Likhvinian (Holsteinian in N-W Europe) type. Indicated Pinus-Picea-Betula forest with broad-leaved trees admixture, coniferous and birch pollen dominate in the spore and pollen spectra, scarce pollen of Carpinus, Quercus, Ulmus, Tillia and tertiary pollen of Juglans sp., Liquidambar, Tsuga are also present (Apukhtin and Ekman, 1967; Agranova and Gaigerova, 1973; Ekman, 1987). Any sediments of glacial Kaluzhsky horizon (MIS 10) are not known in Kola-Karelian region. Marine deposits correlated to the Chekalinsky horizon (MIS 9) were identified according to multi-proxy data and geochronometrically dated in southern Kola Peninsula on the right bank of the Lower Varzuga River (Korsakova et al., 2018). The basal part of the Varzuga key section ( $66.3961 \mathrm{~N} ; 36.6497 \mathrm{E})$ is represented by superposition of consolidated clay, loam, sandy loam with subfossil mollusc shells ESR dated between 319 and 316 ka B.P. Recurring vegetative assemblages are characterized by increasing quantity of Betula sect. Albae with occurrence of mesophilous and thermophilous components, such as Alnus, Quercus, Tilia, Ulmus, Carpinus, Corylus, Osmunda, Nuphar, Nymphaea, indicate here several Middle Neopleistocene warm climatic events. The Middle Neopleistocene Vologodsky (MIS 8) and Gorkinsky (MIS 7) horizons are probably presented in the Varzuga key section too (Korsakova et al., 2018); the key site Kolodozero (61.78430 N; 37.73372 E) provide the spore-pollen evidence of these both units in the S-E Karelia (Agranova et al., 1977). Till and melt-water deposits of the Moskowsky (MIS 6) horizon are known in numerous outcrops from Kola and southern Karelia. The key-sections are situated in the head of the Svyatoi Nos Bay of the Barents Sea (68.0328 N; 39.8736 E), in the valleys of the Lower Chapoma (66.1131 N; 38.8442 E), Ponoi (67.0781 N; 41.1313 E), and Malaya Kachkovka (c. 67.4 N; 40.9 E) Rivers, in the Petrozavodsk area on the Onega Lake terraces (61.8122 N; 34.3292 E and 61.8103 N; 34.3342 E) (Gudina, Yevzerov, 1973; Koprsakova, 2009; Korsakova et al., 2016; Devyatova, 1972; Ikonen, Ekman, 2001).

Upper Neopleistocene (Table 1) incorporates Mikulinsky (MIS 5), Podpopozhsky (MIS 4), Leningradsky (MIS 3) and Ostashkovsky (MIS 2) horizons (Zastrozhnov et al., 2014). Generally represented by marine and brackish-water sediments, Mikulinsky (MIS 5) horizon includes the both Ponoi and Strelna Beds identified in the Kola Upper Neopleistocene stratigraphy. The ESR/OSL-age of the Ponoi Beds and Strelna one ranges from approximately $120-130$ to $100-105 \mathrm{ka}$ (MIS 5e-d) and 100-105 to 70-80 ka (MIS 5c-a), correspondingly (Korsakova, 2009). The key sections are situated in the valleys of the Strelna (66.0983 N; 38.5269 E), Chapoma 66.1131(N; 38.8442 E), Malaya Kachkovka (c. 67.4 N; 40.9 E), and Ponoi 67.0781(N; 41.1313 E) Rivers (Gudina, Yevzerov, 1973; Korsakova, 2009; Korsakova et al., 2016). Multi-proxy data from Ponoi Beds indicate more favorable environments as compared with the modern one; indicated from the Strelna Beds, environments are close to the modern one or colder. Three key sections in the Petrozavodsk area (c. 61.8122 N; 34.3292 E; c. 61.8103 N; 34.3342 E; c. 61.7497 N; 34.4254 E) in southern Karelia proved the sediment succession included interglacial marine and lacustrine sand, silty clay, silt, and clay with Mikulinian spore and pollen spectra (Devyatova, 1972; Ikonen, Ekman, 2001). Glacial deposits of the Podporozhsky (MIS 4) horizon are known from the central and western Kola region 
and from southern Karelia. Two natural exposures with Podporozhian till, melt-water and glaciomarine sediments have been found on the Tersky Coast of the White Sea in the outcrops from Chavanga (66.1508 N; 37.7819 E) and Kamenka (66.0844 N; 38.2861 E) River valleys; they are known from borehole in the Lovozero Tundra Mountains (c. 67.8125 N; 34.9424 E) (Grave et al., 1964; Korsakova, 2009). Glacial diamicton and melt-water sands were identified in the key sections Petrozavodsk (61.7983 N; E 34.3694) and Kukovka (61.7692 N; 34.3800 E) in southern Karelia. These deposits are overlaid here by interstadial Leningradian (MIS 3) lacustrine sand or peat. Interstadial Leningrad horizon sediment from both mentioned sections and from the key section Drevlyanka (c. $61.75 \mathrm{~N} ; 34.33$ E) have been yielded ages $43900 \pm 900,41800 \pm 950,38700 \pm 850,31750 \pm 500{ }^{14} \mathrm{C}$ yr. BP (Ekman, 1982; Ekman, Liyva, 1980). In the Kola region, the Kamenka key site/section $(66.0844$ N; $38.2861 \mathrm{E})$ provides a record of Valdaian (middle and late Weichselian in N-W Europe) glacial and marine deposition. ESR-dated to about $59 \mathrm{ka}$ and $52 \mathrm{ka}$, marine loam and sand correlate here to the Leningrad horizon. In addition, interstadial peats and lacustrine sands are known from the Kovdor open pit (c. 67.554 N; $30.455 \mathrm{E}$ ) in the western Kola, and from boreholes in the Lovozero Mnts (c. 67.8125 N; 34.9424 E) (Grave et al., 1964; Yevzerov, Koshechkin, 1980). Till and melt-water sediments of glacial Ostashkovsky (MIS 2) horizon have a landforming value in the KolaKarelian region.

Acknowledgements. This is a contribution to the research project GI KSC RAS № 0226-2019-0054.

\section{References}

1. Agranova D.A., Baranovskaya O.F., Travina M.A., Epshtein E.S. Morskie srednepleistotsenovye otlozheniya v yugo-vostochnoy Karelii [Marine middle Pleistocene deposits in the South-Eastern Karelia] / Stratigrafiya i paleogeografiya chetvertichnogo perioda Severa evropeiskoi chasti SSSR [Quaternary stratigraphy and paleogeography of the North of European part of the USSR]. Petrozavodsk: Karelian Branch of the Academy of Sciences of the USSR. 1977. P. 111-118 (in Russian).

2. Agranova D.A., Gaigerova L.A., Flory drevnechetvertichnykh otlozheniy Juzhnoy Karelii i Vologodskoy oblasti [Flora from ancient Quaternary deposits in southern Karelia and Vologda district] / Palinologiya pleistotsena i pliotsena: Tdudy III Mezhdynarodnoy palinologicheskoy konferentsii [Pleistocene and Pliocene Palynology: Processing of III International Palynological Conference]. Moskow: Nauka. 1973. P. 32-36 (in Russian).

3. Akromovskiy I.I., Astafiev B.Yu., Belyaev A.M., Bogdanov Yu. B., Voinov A.S., Voinova O.A., Guseva E.N., Egirov S.V., Zarrina E.P., Klyushkin A.V., Legkova V.N., Petrov B.V. Gosudarstvennaya geologicheskaya karta Rossiyskoy Federatsii, Masshtab 1:1 000000 (novaya seriya). List P-(35)-37 - Petrozavodsk. Obiasnitelnaya zapiska [National Map of the Russian Federation, scale 1:1 000000 (new series), Sheet P-(35)-37 - Petrozavodsk. Explanatory Note]. St. Petersburg: VSEGEI kartfabrica Press. 2000. (in Russian).

4. Apukhtin Y.I., Ekman I.M. Stratigrafiya. Murmanskaya oblast, Kareliya, zapad Arkhangelskoy, severo-zapad Vologodskoy i sever Leningradskoy oblastey [Stratigraphy. Murmansk district, Karelia, Western Arkhangelsk district, North-Western Vologda and Northern Leningrad ones] / Geologiya chetvertichnykh otlozheniy SeveroZapada evropeiskoy chasti SSSR [Quaternary geology of the North-Western part of the European USSR]. Leningrad: Nedra. 1967. P. 48-110 (in Russian).

5. Cohen K.M. Gibbard P. Global chronostratigraphical correlation table for the last 2.7 million years. Subcommission on Quaternary Stratigraphy (International Commission on Stratigraphy). 2011. Cambridge, England. http:// quaternary.stratigraphy.org/charts/.

6. Devyatova E.I., Palinologicheskaya kharakteristika verkhnechetvertichnykh otlogeniy Karelii [Palinology of the Upper Quaternary deposits in Karelia] / Chetvertichnaya geologiya i geomorfologiya vostochnoy chasti Baltiyskogo zhchita [Quaternary geology and geomorphology of the western part of Baltic Shield]. Leningrad: Nauka. 1972. P. 59-96 (in Russian).

7. Ekman I.M. Chetvertichnaya Sistema [Quaternary System] / Geologiya Karelii [Geology of Kareia]. Leningrad: Nauka. 1987. P. 79-93 (in Russian).

8. Ekman I.M., Liyva A.A. Ob absoljutnoy khronologii «bolshogo» Vjurma-Valdaya na Onezhsko-Ladozhskom peresheike (po dannym ${ }^{14} \mathrm{C}$ datirovok) [About of absolute chronology of the Würm-Valdai, in the wide sense, on the Onega-Ladoga Isthmus (according to ${ }^{14} \mathrm{C}$-data)] / Geokhronologiya chenvertichnogo perioda [Geochronology of the Quaternary]. Moscow: Nauka.1980. P. 54-68 (in Russian).

9. Gudina V.I., Yevzerov V.Ya. The stratigraphy and foraminifera of the Upper Pleistocene in the Kola Peninsula. The British Library Board. 1981. (Translated by Lees, E., Edited by Hugnes, M).

10. Grave M.K, Yevzerov V.Ya., Likhachev A.B., Spicin A.G., Novye dannye o rykhlykh otlozheniyakh i formirovanii reliefa Seidozerskogo rayona (Lovozerskiye Tundry) [New data on detrital deposits and relief formation of 
Seydozero area (Lovozero Tundra)] / Relief i geologicheskoe stroenie osadochnogo pokrova Kolskogo poluostrova [Relief and geological structure of the sedimentary cover of the Kola Peninsula]. Moscow-Leningrad: Nauka. 1964. P. 5-47 (in Russian).

11. Head M.J., Gibbard P.L. Formal subdivision of the Quaternary System/Period: Past, present, and future // Quaternary International. 2015. V. 383. P. 4-35.

12. Ikonen L, Ekman I. Biostratigraphy of the Mikulino interglacial sediments in NW Russia: the Petrozavodsk site and a literature review. Annales Academiae Scientiarum Fennicae A III Geologica-Geographica. 2001. V. 161.

13. Korsakova O.P. Pleistocene marine deposits in the coastal areas of Kola Peninsula (Russia) // Quaternary International. 2009. V. 206. P. 3-15.

14. Korsakova O., Kolka V., Semenova L. Late Pleistocene stratigraphy according to the sediment sequence from eastern Kola Peninsula, Ponoi River Valley (North-Western Russia) // Quaternary International. 2016. V. 420. P. 280-293.

15. Korsakova O., Molodkov A., Yelovicheva Ya., Kolka V. Middle Pleistocene marine deposits on the Kola Peninsula (NW Russia) // Quaternary International. 2018. https://doi.org/10.1016/j.quaint.2018.09.019.

16. Yevzerov V.Ya, Koshechkin B.I. Paleogeografiya pleistotsena zapadnoy chasti Kolskogo poluostrova [Paleogeography of the western Kola Peninsula]. Leningrad: Nauka. 1980 (in Russian).

17. Zastrozhnov A.S. (Ed). Karta chetvertichnykh obrazovanyi territorii Rossiyskoi Federatsii. Masshtab 1:2500000 (A map of Quaternary deposits of the Russian Federation territory. Scale 1:2500000). Saint-Petersburg: All-Russian Geological Institute (VSEGEI) Press. 2014. http://www.vsegei.com/ru/info/quaternary-2500/ (in Russian).

18. Zhamoida A.I., Girshgorn L.C.H., Kovalevsky O.P., et all. Stratigraphichesky kodeks Rossii, isdanie tretie [Stratigraphic Code of Russia, third edition]. Sankt Petersburg: VSEGEI Press. 2006 (in Russian). 